\title{
Defoliation of Woody Cut Stems with Preharvest, Less Toxic Chemical and Postharvest Environmental Methods
}

Lane Greer ${ }^{1}$ and John M. Dole ${ }^{2}$

\begin{abstract}
AdDitional Index wORDs. Celastrus scandens, Salix matsudana, Callicarpa americana, Ilex verticillata, chelated copper, dimethipin, crop oil concentrate, acetic acid, pelargonic acid, abscission
\end{abstract}

Summary. Six defoliants were applied in fall and tested for their efficacy in preharvest defoliation of fieldgrown curly willow (Salix matsudana 'Tortuosa'), american bittersweet (Celastrus scandens), and american beautyberry (Callicarpa americana). Defoliants included acetic acid, chelated copper, crop oil concentrate surfactant (COC), ethephon, dimethipin plus COC, pelargonic acid, and a tap water control. For chelated copper, a concentration of $800 \mathrm{mg} \cdot \mathrm{L}^{-1}$ (ppm) was most effective at promoting defoliation, providing $100 \%$ defoliation of american bittersweet and $76 \%$ defoliation of american beautyberry. For curly willow and american beautyberry, all concentrations of dimethipin produced good or excellent defoliation. Increasing concentrations of ethephon from 200 to $2500 \mathrm{mg} \cdot \mathrm{L}^{-1}$ increased defoliation from $0 \%$ to $67 \%$. Pelargonic acid was not effective at promoting defoliation of woody plants at the concentrations used. In an experiment conducted during spring using containerized curly willow, irrigation was stopped

${ }^{1}$ Assistant Professor, Mississippi State University, Box 9555, Mississippi State, MS 39762; lgreer@pss. msstate.edu

${ }^{2}$ Professor, North Carolina State University, Box 7609 , Raleigh, NC 27695

Use of trade names in this publication does not imply endorsement by the authors of products named or criticism of similar ones not mentioned. The authors would like to thank the Association of Specialty Cut Flower Growers for supplying funds to complete the research; John Zehrer and Alex and Betsy Hitt for supplying plant material; Uniroyal Chemical for supplying defoliant; Fafard for potting media; Dillen Plastics for pots; and Harold F. Wilkins, Scott Acre, Diane Mays, and Jessica Hyatt for assistance in defoliant application. 
for $\mathbf{0 , 3}$, or 6 days before defoliants were applied, but none of the irrigation treatments promoted defoliation. In a postharvest study using cut curly willow, stems were held in distilled water at 5,20 , or $35^{\circ} \mathrm{C}(41.0,68.0$, or $95.0{ }^{\circ} \mathrm{F}$ ) for $1,3,5$, or 7 days. Holding cut stems of curly willow at $20{ }^{\circ} \mathrm{C}$ promoted $68 \%$ defoliation, compared to $53 \%$ or $28 \%$ for 5 or 35 ${ }^{\circ} \mathrm{C}$, respectively.

$\mathrm{W}$ oody cuts valued for their fruit or stem, such as american bittersweet and curly willow, are usually sold without foliage. Removal of foliage prior to harvest results in less postharvest debris and more aesthetically pleasing stems. Currently, woody cuts are defoliated either by hand or by preharvest application of defoliants or desiccants normally used to facilitate mechanical harvesting of crops such as cotton (Gossypium birsutum) and grapes (Vitis vinifera) (Yang, 1986). Defoliants have numerous disadvantages: they are potentially toxic to plants (Morgan, 1985) and humans (Scarborough et al., 1989), may have unpleasant odors, increase production costs (Morgan, 1985), and produce inconsistent defoliation (Cathey, 1980). Thus, there is a need to improve the consistency while reducing the hazards and costs of defoliants and desiccants (Morgan, 1985). Less-toxic herbicides may provide an alternative to defoliants.

Pelargonic acid (Scythe; Mycogen Corp., San Diego, Calif.) is a contact, nonselective, nonresidual, foliar herbicide that disrupts cells and desiccates green tissue rapidly (Biconet, 1998). Pline et al. (2000) observed that a 3\% $(\mathrm{v} / \mathrm{v})$ concentration of pelargonic acid was phytotoxic to common lambsquarters (Chenopodium album), sicklepod (Senna obtusifolia), and giant foxtail (Setaria faberi). The recommended concentration for use of Scythe (57\% a.i., $\mathrm{pH} 3.75)$ as an herbicide is $1: 20$ or $1: 10$ (concentrate : water).

Acetic acid is the active ingredient in the contact herbicide Burnout (23.15\% a.i., pH 1.85; St. Gabriel Labs, Gainesville, Va.). Extracts from lemon juice are included as an inert ingredient. Acetic acid may be used as a postemergent, nonselective, foliar herbicide recommended for use on immature annual and perennial dicotyledons and monocotyledons.

Chelated copper is the primary ingredient of Captain (SePro Corp., Carmel, Ind.) (9.09\% a.i., pH 10.1), registered as an aquatic algaecide. Cupric ethylenediaminetetracetic acid (CuEDTA), another form of chelated copper, at a concentration of $0.1 \%$ was effective in increasing ethylene production in citrus fruit (Rasmussen and Cooper, 1968).

Ethephon (Florel; Bayer Crop Science, Research Triangle Park, N.C.) has been used to defoliate cotton, citrus (Citrus spp.) (Rasmussen and Cooper, 1968), and sour cherry (Prunus cerasus) (Olien and Bukovac, 1978) with varying results. Larsen (1973) found that ethephon at $750 \mathrm{mg} \cdot \mathrm{L}^{-1}$ was effective for defoliation of apple (Malus) trees.

Dimethipin (Harvade 5F; Uniroyal Chemical, Middlebury, Conn.) is used as a cotton defoliant and is a weak inhibitor of regrowth (Brecke et al., 2001 ). The recommended concentration for Harvade ( $48 \%$ a.i., $\mathrm{pH} 8.0$ ) as a cotton defoliant varies with time of year, age of crop, and environmental conditions. Two applications of dimethipin at $200 \mathrm{mg} \cdot \mathrm{L}^{-1}$, combined with $2 \%$ surfactant, successfully defoliated edible fig (Ficus carica) nursery stock (Dozier et al., 1987). Dimethipin applied at $1600 \mathrm{mg} \cdot \mathrm{L}^{-1}$ gave $71 \%$ leaf drop and $1 \%$ berry drop of deciduous holly (Ilex verticillata) (Banko and Stefani, 1999).

Postharvest defoliation through manipulation of a controlled environment may be possible. Environmental changes such as drought can also induce leaf abscission (Osborne, 1989). Reduced carbohydrate levels and water stress induced leaf abscission in several plant species including poinsettia (Euphorbia pulcherrima) (Dole and Wilkins, 1999) and rose (Rosa spp.) (Morgan et al., 1990). Cool temperatures, such as a light frost, encourage changes in leaf metabolism and lead to abscission.

The overall objective of this project was to find an effective, least-toxic method for early leaf abscission in woody cuts through chemical application or environmental manipulation, without concurrent fruit drop or plant necrosis. The objective of the preharvest field studies was to evaluate the effectiveness of six defoliants on three species of woody plants. The objectives of the preharvest greenhouse study were to: 1) assess spring defoliation using five defoliants; 2 ) investigate in- teractions between irrigation cessation and defoliants; and 3 ) determine the effects of defoliants on regenerative leaf ability. The objective of the postharvest study was to determine the effect of temperature and storage on defoliation of woody cut stems.

\section{Materials and methods}

Preharvest Defoliation. In the first experiment, 11 treatments were applied to 3-year-old, field-grown curly willow plants in Raleigh, N.C. Curly willow was chosen because the stems are easily produced by growers and often used by florists. No previous literature was available to suggest appropriate concentrations for defoliation, so initial concentrations of onethird to one-half the recommended herbicide usage rate were chosen to prevent plant necrosis. The treatments included acetic acid at 1500 or 2000 $\mathrm{mg} \cdot \mathrm{L}^{-1}$, chelated copper at 100 or 200 $\mathrm{mg} \cdot \mathrm{L}^{-1}$, ClawEl crop oil concentrate surfactant $[1 \% \mathrm{v} / \mathrm{v}$ (Brandt Consolidated, Pleasant Plains, Ill.)], ethephon at 250 or $500 \mathrm{mg} \cdot \mathrm{L}^{-1}$, dimethipin at 1600 $\mathrm{mg} \cdot \mathrm{L}^{-1}$ plus COC $(1 \% \mathrm{v} / \mathrm{v})$, pelargonic acid at 100 or $250 \mathrm{mg} \cdot \mathrm{L}^{-1}$, and a tap water control. All plants were sprayed to runoff $[\sim 600 \mathrm{~mL}(20.3 \mathrm{fl} \mathrm{oz})$ per plant] with a backpack sprayer. Application was made on 2 Sept. 2002, after foliage matured and stem elongation was complete. Air temperature ranged from 18.9 to $23.9^{\circ} \mathrm{C}$ (66 to $75^{\circ} \mathrm{F}$ ), relative humidity ranged from $75 \%$ to $90 \%$, and no precipitation occurred for $12 \mathrm{~d}$ after defoliant application. Data collected included dates of $10 \%$ of foliage yellowing, and $50 \%, 75 \%$, and $90 \%$ defoliation. Experimental design was a randomized complete block with five replications per treatment. Data were analyzed by general linear model procedure with means comparison by orthogonal contrasts (SAS Institute, Cary, N.C.).

For the second experiment, 12 treatments were applied to mature, field-grown american bittersweet in Soldiers Grove, Wis., in Oct. 2002, before fruits had fully colored. Like curly willow, american bittersweet is a commonly grown and sold cut stem. Plants were sprayed to runoff $[\sim 400$ $\mathrm{mL}$ ( $13.5 \mathrm{floz}$ ) per plant $]$. Air temperature ranged from 5.6 to $15.0{ }^{\circ} \mathrm{C}(42$ to $59{ }^{\circ} \mathrm{F}$ ); relative humidity was $90 \%$ to $100 \%$, and a rain event occurred 2 $\mathrm{h}$ after defoliant application. Chemicals and concentrations used were: acetic 
acid at 2000,3000 , or $4000 \mathrm{mg} \cdot \mathrm{L}^{-1}$; chelated copper at 200,400 , or 800 $\mathrm{mg} \cdot \mathrm{L}^{-1}$; ethephon at $1000 \mathrm{mg} \cdot \mathrm{L}^{-1}$; dimethipin at $1600 \mathrm{mg} \cdot \mathrm{L}^{-1}$ plus $1 \%$ (v/v) COC; pelargonic acid at 250, 500 , or $1000 \mathrm{mg} \cdot \mathrm{L}^{-1}$; and a tap water control. Data were collected $10 \mathrm{~d}$ after treatment on percent defoliation and fruit drop. Experimental design was a completely randomized block with five replications per treatment. Data were analyzed by general linear model procedure with means separation by orthogonal contrasts (SAS Institute).

For the third experiment, 2-yearold, field-grown american beautyberry plants were sprayed to runoff $[\sim 200 \mathrm{~mL}$ (6.8 $\mathrm{fl} \mathrm{oz}$ ) per plant] using a backpack sprayer in Raleigh, N.C., on 9 Oct. 2003. Stems of american beautyberry are not as commonly grown as curly willow and american bittersweet, but numerous growers in the Southeast produce and market the fruiting stems. Treatments included chelated copper at 800,1000 , or $1200 \mathrm{mg} \cdot \mathrm{L}^{-1}$; dimethipin at $1200,1400,1600$, or 1800 $\mathrm{mg} \cdot \mathrm{L}^{-1}$; ethephon at 1000,1500 , 2000 , or $2500 \mathrm{mg} \cdot \mathrm{L}^{-1}$; and a tap water control. Air temperatures ranged from 17.2 to $21.1^{\circ} \mathrm{C}\left(63\right.$ to $\left.70{ }^{\circ} \mathrm{F}\right)$, relative humidity ranged from $59 \%$ to $76 \%$, and no precipitation occurred for $1 \mathrm{~d}$ after defoliant application. Data collected included percent defoliation and fruit drop. Experimental design was a completely randomized block with five replications per treatment. Data were analyzed by general linear model procedure with means separation by orthogonal contrasts (SAS Institute).

For the fourth experiment, a greenhouse study was conducted in Spring 2003 using curly willow. Six-inch-long $(15.2 \mathrm{~cm})$ curly willow cuttings were rooted and grown for 5 months in the greenhouse in 12.7 -cm-diameter (5 inches) standard plastic pots containing Fafard $4 \mathrm{P}$ potting media (Fafard, Anderson, S.C.). Plants were hand watered and fertilized weekly with $150 \mathrm{mg} \cdot \mathrm{L}^{-1} \mathrm{~N}$ of Peters $20 \mathrm{~N}-4.4 \mathrm{P}-16.6 \mathrm{~K}$ (J.R. Peters, Allentown, $\mathrm{Pa}$.). At the time of treatment, plants were 3 to $4 \mathrm{ft}(0.9$ to $1.2 \mathrm{~m}$ ) tall with fully developed root systems and two to five branches. Experimental design was completely randomized with nine defoliant concentrations, three irrigation timings, and eight replications per treatment. Defoliants included chelated copper at 400 or $800 \mathrm{mg} \cdot \mathrm{L}^{-1}, 1 \%(\mathrm{v} / \mathrm{v}) \mathrm{COC}$, ethephon at 1000 or $1500 \mathrm{mg} \cdot \mathrm{L}^{-1}$, dimethipin at $1600 \mathrm{mg} \cdot \mathrm{L}^{-1}$ plus $1 \%$ (v/v) COC, pelargonic acid at 1000 or $1500 \mathrm{mg} \cdot \mathrm{L}^{-1}$, and a tap water control. For the three irrigation timings, plants were irrigated daily (control), or irrigation was stopped 3 or $6 \mathrm{~d}$ before treatment to simulate mild or severe water stress, respectively. All defoliants were sprayed to runoff $(\sim 200 \mathrm{~mL}$ per plant) using backpack sprayers. Plants were observed daily for 2 weeks, and again 6 weeks after treatment. Data collected included dates of first dropped leaf, $50 \%$ defoliation, and $90 \%$ defoliation. At the termination of the experiment, quality ratings of 1 to 5 , with 1 having all leaves present and 5 having no leaves present, were made. Data were analyzed by general linear model procedure with means separation by least significant differences (SAS Institute).

Postharvest Defoliation. In Oct. and Nov. 2002, stems of fieldgrown curly willow and american beautyberry were cut and placed in distilled (DI) water for transport to the postharvest treatment area. Cut stems were then placed in DI water for $1,3,5$, or $7 \mathrm{~d}$ at temperatures of 5,20 , or $35^{\circ} \mathrm{C}$ under cool-white fluorescent lights $\left(30 \mu \mathrm{mol} \cdot \mathrm{m}^{-1} \cdot \mathrm{s}^{-2}\right)$ for $12 \mathrm{~h} \cdot \mathrm{d}^{-1}$. After treatment, stems were placed in DI at $20^{\circ} \mathrm{C}$. Ten days after treatment, jars containing stems

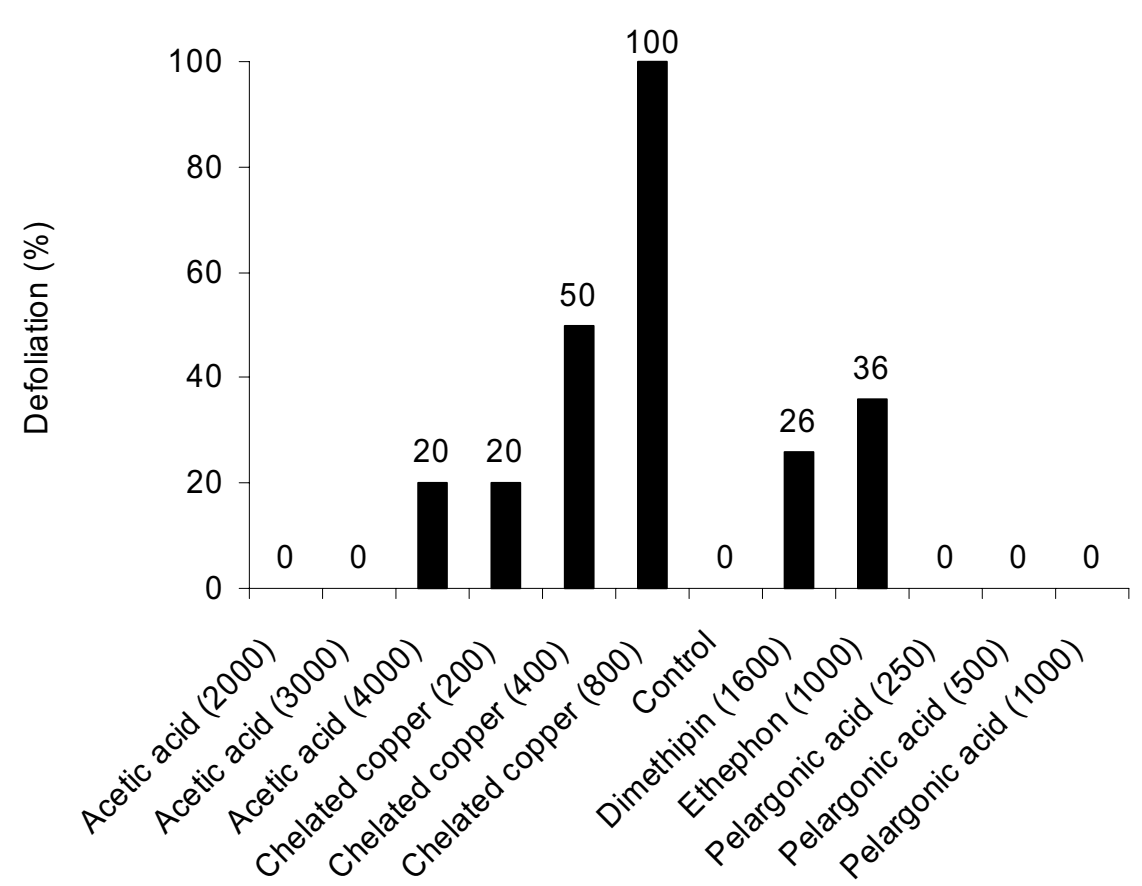

Fig. 1. Mean percentage defoliation of american bittersweet after defoliants $\left[\mathrm{mg} \cdot \mathrm{L}^{-1}(\mathrm{ppm})\right]$ were applied to field-grown plants at Soldiers Grove, Wis., in Oct. 2002 (five replications). (SAS Institute).

\section{Results and discussion} or necrosis. tion, as opposed to plant necrosis. were tapped 3 times on an extruded metal bench and percent defoliation recorded. For american beautyberry, the number of dropped fruit per stem was also recorded. The experimental design was a $3 \times 4$ factorial in a completely randomized block design with 10 replications. Data were analyzed by general linear model procedure with means separation by trend analysis

Preharvest Defoliation. In the first experiment, dimethipin applied at $1600 \mathrm{mg} \cdot \mathrm{L}^{-1}$ produced significant leaf necrosis $(P \leq 0.05)$ of willow $2 \mathrm{~d}$ after treatment (DAT) (data not presented). Slight agitation of the stems resulted in leaf drop. Ethephon applied at 500 $\mathrm{mg} \cdot \mathrm{L}^{-1}$ produced $10 \%$ foliage chlorosis 6 DAT, but the foliage did not exhibit further chlorosis, necrosis, or drop. No other treatments produced chlorosis

Concentrations of all defoliants except dimethipin may have been too low to produce defoliation. The selected concentrations were chosen because no literature was available on concentrations appropriate for defolia-

In experiment two conducted with american bittersweet, there was a linear response to concentrations of chelated copper (Fig. 1), with 400 or 
$800 \mathrm{mg} \cdot \mathrm{L}^{-1}$ concentrations producing $50 \%$ or $100 \%$ autonomous defoliation, respectively. There was an increasing linear response to acetic acid, but the highest concentration $\left(4000 \mathrm{mg} \cdot \mathrm{L}^{-1}\right)$ was not significantly different from the control. Dimethipin at $1600 \mathrm{mg} \cdot \mathrm{L}^{-1}$ provided $26 \%$ defoliation. The label for dimethipin recommends a 6 -h rain-free period following application, and a rain event occurring $2 \mathrm{~h}$ after application may have contributed to the decreased defoliation compared to the other field experiments. Ethephon at $1000 \mathrm{mg} \cdot \mathrm{L}^{-1}$ provided $36 \%$ defoliation and encouraged fruit ripening and opening, but no treatment significantly increased fruit drop. No concentration of pelargonic acid was more effective than the control for defoliating american bittersweet.

In experiment three, all treatments except for ethephon at 1000 $\mathrm{mg} \cdot \mathrm{L}^{-1}$ provided greater autonomous defoliation of american beautyberry than the control $(P \leq 0.05)$ (Fig. 2). All concentrations of dimethipin provided equal defoliation (95\% to $100 \%$ ). There was an increasing linear trend for ethephon, with defoliation increasing from $24 \%$ to $58 \%$ as concentration increased from 1000 to $2500 \mathrm{mg} \cdot \mathrm{L}^{-1}$. There was a decreasing linear response for chelated copper, with the 800 and $1000 \mathrm{mg} \cdot \mathrm{L}^{-1}$ concentrations providing $77 \%$ and $76 \%$ defoliation, respectively. The $1200 \mathrm{mg} \cdot \mathrm{L}^{-1}$ concentration of chelated copper produced $45 \%$ defoliation. Cooper et al. (1968) state that chemicals causing mild leaf injury are more effective for defoliation, with more caustic chemicals causing "rapid tissue inactivation, death, and freezing of the foliage." The high concentration of chelated copper may have killed the abscission layer cells too quickly and did not permit leaf drop.

In experiment four, dimethipin promoted $88 \%$ defoliation $(P \leq 0.05)$ of curly willow (Fig. 3) and was the only treatment significantly different from the control. However, the dimethipin solution, which contained COC, was not significantly different from the COC solution alone, which promoted $83 \%$ defoliation. No irrigation treatment promoted defoliation, and no interaction occurred between herbicide and irrigation treatments (data not presented). The oldest leaves dropped first. Next to abscise were the youngest leaves, and middle leaves were last to drop or did not drop. No

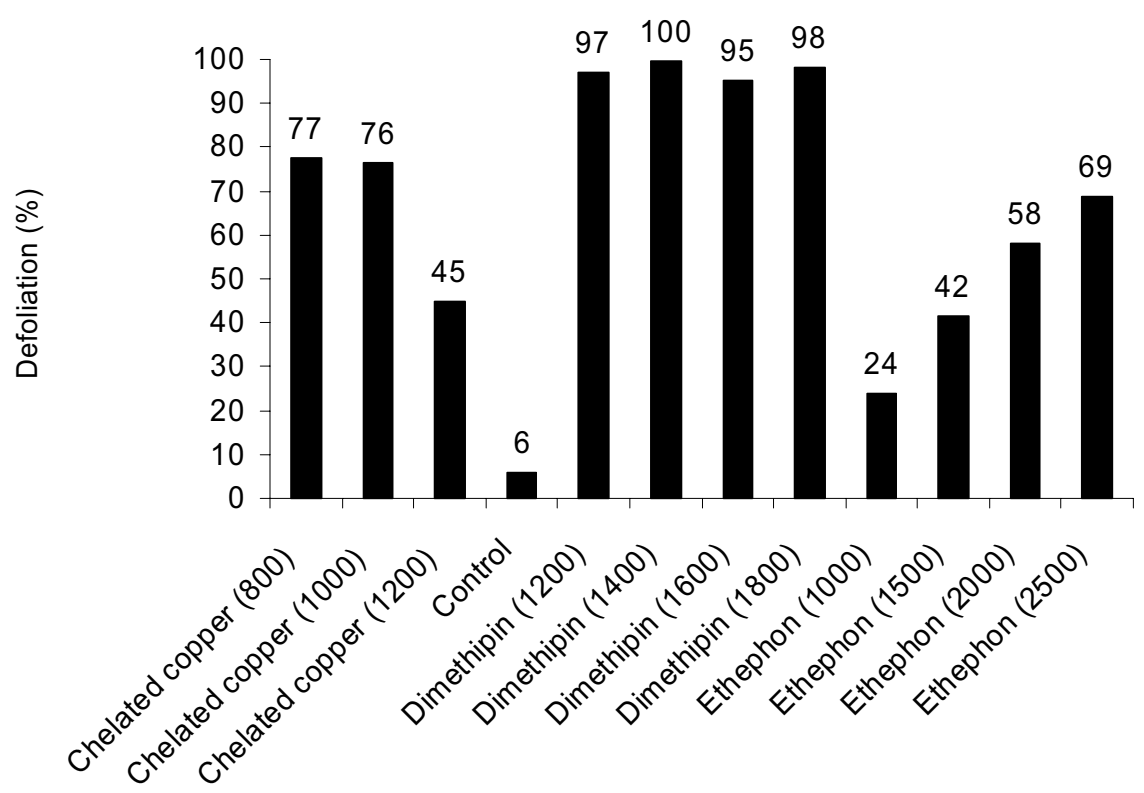

Fig. 2. Mean percentage defoliation of american beautyberry after defoliants $\left[\mathrm{mg} \cdot \mathrm{L}^{-1}(\mathrm{ppm})\right]$ were applied to field-grown plants at Raleigh, N.C., in Oct. 2003 (five replications).

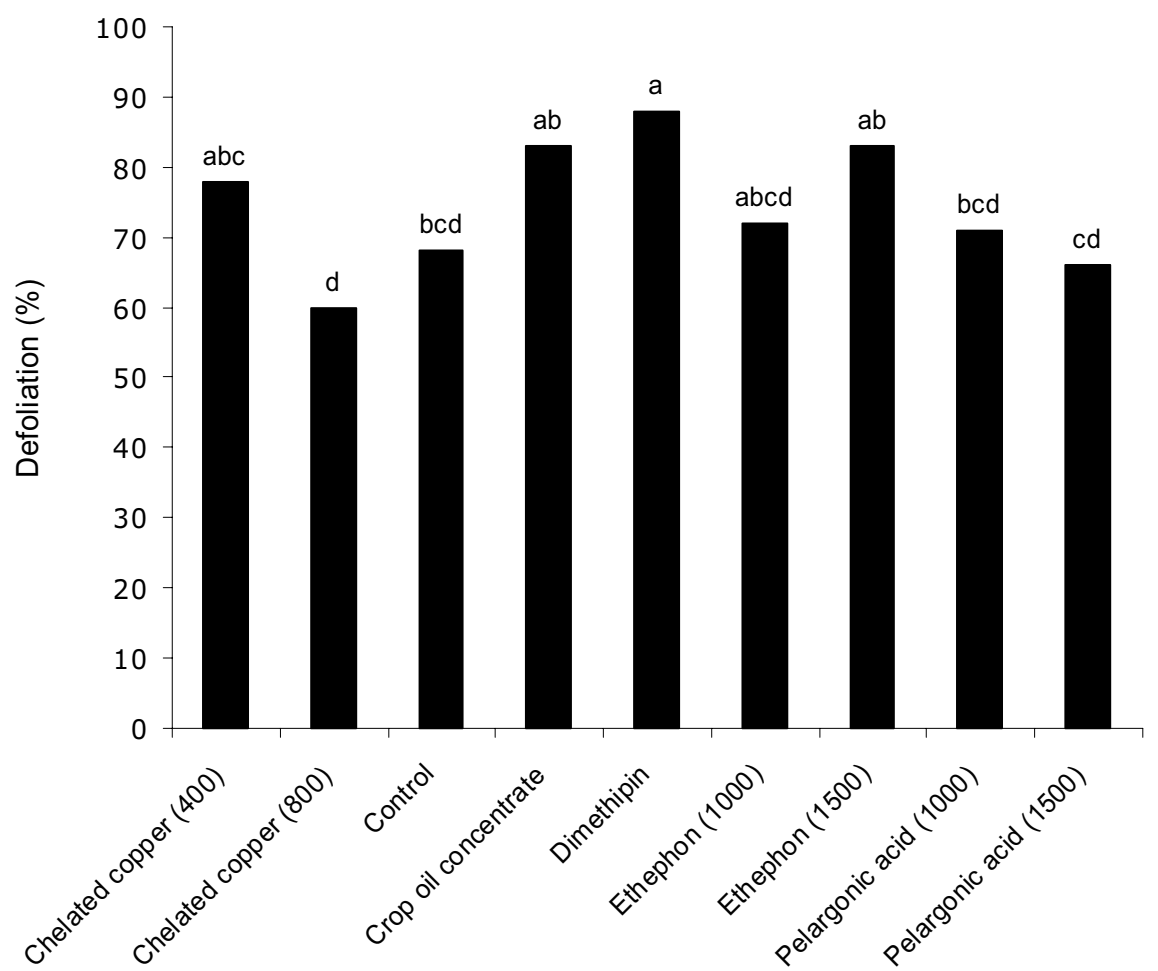

Fig. 3. Mean percentage defoliation of greenhouse-grown curly willow after defoliants $\left[\mathrm{mg} \cdot \mathrm{L}^{-1}(\mathrm{ppm})\right]$ were applied (five replications). Bars marked with the same letter are not significantly different using least significant difference at $P \leq$ 0.05 . 
treatment adversely affected plants, with regrowth occurring on all plants 6 weeks after treatment.

The results from experiment four indicate that spring defoliation may differ from fall. It is possible that application of defoliants to stems during the middle of the growth season is less likely to result in defoliation because leaves have not yet formed an abscission zone.

Postharvest defoliation. Holding willow stems at $20^{\circ} \mathrm{C}$ significantly increased defoliation to $68 \%(P \leq 0.05)$, compared to $53 \%$ for stems held at $5{ }^{\circ} \mathrm{C}$ and $28 \%$ for stems held at $35{ }^{\circ} \mathrm{C}$ (data not presented). There was a significant temperature $\times$ time interaction: stems held at $35^{\circ} \mathrm{C}$ for $1 \mathrm{~d}$ lost $44 \%$ of foliage, those held for $3 \mathrm{~d}$ lost $48 \%$, those held for $5 \mathrm{~d}$ lost $11 \%$, and those held for 7 d lost $8 \%$ of their foliage. Holding cut american beautyberry stems at 5,20 , or $35^{\circ} \mathrm{C}$ did not promote leaf or fruit drop (data not presented).

Cold and heat can induce leaf abscission when brought on gradually, but severe or immediate introduction to extreme temperatures can induce the opposite reaction (Addicott, 1982). Extremely low or high temperatures can injure or kill the abscission zone cells, so that physiological separation cannot occur (Addicott, 1982). Additionally, water stress brought on by high temperatures can induce abscission, but only if the abscission zone cells remain viable. The 5 and $35^{\circ} \mathrm{C}$ treatments used in this study may have produced more defoliation if the stems had been introduced to the different environments more gradually. As was stated above, it is possible that stems cut during the middle of the growth season had not formed an abscission zone, or that the extreme temperatures rapidly killed existing abscission zone cells.

\section{Conclusions}

Efficacy of preharvest defoliation using chemicals will depend on type and concentration of chemical, as well as species and environmental conditions. Further research should focus on the defoliants that showed greatest promise, including ethephon concentrations of $2500 \mathrm{mg} \cdot \mathrm{L}^{-1}$ or higher, dimethipin concentrations of $1200 \mathrm{mg} \cdot \mathrm{L}^{-1}$ or lower, and chelated copper at $800 \mathrm{mg} \cdot \mathrm{L}^{-1}$. Economics may also dictate what defoliant is used. Ethephon spray solution at $2500 \mathrm{mg} \cdot \mathrm{L}^{-1}$ costs $\$ 1.35 / \mathrm{L}(\$ 5.11 / \mathrm{gal})$, whereas an $800 \mathrm{mg} \cdot \mathrm{L}^{-1}$ concentration of chelated copper costs $\$ 0.07 / \mathrm{L}(\$ .26 / \mathrm{gal})$, and dimethipin at $1200 \mathrm{mg} \cdot \mathrm{L}^{-1}$ costs $\$ 0.06 / \mathrm{L}(\$ .23 / \mathrm{gal})$.

\section{Literature cited}

Addicott, F.T. 1982. Abscission. Univ. of California Press, Berkeley.

Banko, T.J. and M. Stefani. 1999. Defoliation of deciduous holly for cut holly production. Proc. Southern Nursery Assn. Res. Conf. 44:327-329.

Biocontrol Network. 2004. Scythe herbicide. 11 Oct. 2004. <http://www.biconet. com/lawn/pelargonic scytheacid.html>.

Brecke, B.J., J.C. Banks, and J.T. Cothren. 2001. Harvest-aid treatments: Products and application timing, p. 119-142. In: J.R. Supak and C.E. Snipes (eds.). Cotton harvest management: Use and influence of harvest aids. Cotton Foundation, Memphis, Tenn.

Cathey, G.W. 1980. Harvest-aid chemicals and practices for cotton. Outlook Agr. 10:191-197.

Cooper, W.C., G.K. Rasmussen, B.J. Rogers, P.C. Reece, and W.H. Henry. 1968. Control of abscission in agricultural crops and its physiological basis. Plant Physiol. 45:1560-1576.

Dole, J.M. and H.F. Wilkins. 1999. Floriculture: Principles and species. Prentice Hall, Englewood Cliffs, N.J.
Dozier, W.A., C.H. Gilliam, and J.W. Knowles. 1987. Chemical defoliation of fig nursery stock using ethephon, Harvade, and D-WK surfactant. J. Environ. Hort. 5(3):116-119.

Larsen, F.E. 1973. Successful defoliation of nursery stock with chemicals. Combined Proc. Intl. Plant Propagators' Soc. 23:62-70.

Morgan, P.W. 1985. Chemical manipulation of abscission and desiccation. Beltsville Symp. Agr. Res. 8:61-74.

Morgan, P.W., C.J. He, J.A. de Greef, and M.P. de Proft. 1990. Does water deficit stress promote ethylene synthesis by intact plants? Plant Physiol. 94:1616-1624.

Olien, W.C. and M.J. Bukovac. 1978. The effect of temperature on rate of ethylene evolution from ethephon and from ethephon-treated leaves of sour cherry. J. Amer. Soc. Hort. Sci. 103(2):199-202.

Osborne, D.J. 1989. Abscission. Crit. Rev. Plant Sci. 8(2):103-129.

Pline, W.A., K.K. Hatzios, and E.S. Hagood. 2000. Weed and herbicide-resistant soybean (Glycine max) response to glufosinate and glyphosate plus ammonium sulfate and pelargonic acid. Weed Technol. 14:667-674

Rasmussen, G.K. and W.C. Cooper. 1968. Abscission of citrus fruits induced by ethylene-producing chemicals. Proc. Amer. Soc. Hort. Sci. 93:191-198.

Scarborough, M.E., R.G. Ames, M.J. Lipsett, and R.J. Jackson. 1989. Acute health effects of community exposure to cotton defoliants. Arch. Environ. Health 44(6):355-360.

Yang, S.F. 1986. Regulation of plant growth by ethylene and related compounds. p. 212-219. In: Plant growth regulators in agriculture. Food and Fert. Technol. Ctr. for the Asian and Pacific Reg., Book Ser. No. 34, Taipei, Taiwan. 